\title{
The Service-Learning Courses in Ilan University to Promote Nanotech's Popular Science Education
}

\author{
Ming-Ta Wu, Show-Yu Lin, Ya-I. Cho, and Hui-Huang Chen
}

\begin{abstract}
This study introduced the Service-Learning courses in Ilan University, as well as investigated the effectiveness of the service item - popular science education promotion. The undergraduate students who elected these courses (Novel Food Processing, Bio-nanotechnology and Introduction to Food Nanotechnology) voluntarily took part in service-learning program as the seed teachers to promote the nanotech popular science education for $4^{\text {th }}$ to $6^{\text {th }}$ grade students. Seed teachers completed 24 hours extra exercise beyond classroom learning. The self-designed activity - nanotech's popular science education promotion (NPSEP) teaching is carried out, meanwhile, elementary schools students' learning performance were evaluated before and after this activities. We found NPSEP teaching significantly advanced the nanotech learning performance and outcome for these elementary schools students. These undergraduate students also gained a significant advancement in learning target of nanotechnology.
\end{abstract}

Index Terms-Elementary school, nanotechnology, popular science education, service-learning.

\section{INTRODUCTION}

Nanotechnology is regarded as the $4^{\text {th }}$ industrial revolution that will change the industrial structure as well as our lifestyle [1], [2]. For this potential impact brought by nanotechnology, the development of nanotechnology has also drawn a lot of research attention in developed countries all over the world. In the future, the new devices and applications resulted by the new material properties and the technologies for precise measurement derived from the developed nanotechnology will soon be prevalent in many industries. For nanotechnology to reach its full potential to contribute to food science and industry, it must have a workforce to nurture students through nanotechnology education and training programs.

Beyond normal education in primary schools, informal science education includes museums, television, lectures, media, networks, etc., all of which are important implements to connect nano-science knowledge with the population. These popular science modes of educations offer enjoyment from learning, and facilitate effective learning by internet communication [3], image communication [4], written communication [5], lifelong learning [6], distance learning

Manuscript received May 12, 2014; revised July 30, 2014.

M. T. Wu is with the Department of Industrial Management and Enterprise Information, Aletheia University, New Taipei, CO 251 Taiwan (e-mail: mingtawu@ms23.hinet.net).

S. Y. Lin is with the Faculty of Center for General Education, Aletheia University, New Taipei, CO 251 Taiwan (e-mail: sylin8@yahoo.com.tw).

Y. I. Cho and H. H. Chen are with the Faculty of Center for Nanotechnology, National Ilan University, I-Lan, CO 260 Taiwan (e-mail: cho-1@yahoo.com.tw, hhchen@niu.edu.tw).

\section{[7], and experience communication [8].}

Integrated serve-learning is a method for teaching, learning and reflecting that combines academic classroom curriculum with meaningful service (frequently youth service) throughout the community. As a teaching methodology, it falls under the philosophy of experiential education. More specifically, it integrates meaningful community service with instruction and reflection to enrich the learning experience, teach civic responsibility, encourage lifelong civic engagement, and strengthen communities for the common good [9].

For example, enthusiastic and responsible teachers design curricula related to community service to enable students to discuss their feelings in class after a community service engagement. Teachers can also establish official courses offering credits with service activities to achieve the goal of service-learning; this direction of development can help to implement the real meaning of service-learning [10].

The undergraduate students, who elected the service-learning course, voluntarily took part in service-learning program as the seed teachers to promote the nanotech popular science education for $4^{\text {th }}$ to $9^{\text {th }}$ grade students. This design was used to train these seed teachers to "learn" through "services" of an integrated social service for science courses. Moreover, the elementary school students could thereby gain a preliminary understanding and interesting about nanotechnology particular in food category. This study introduced the food nanotechnology education in Taiwan, and investigated the effectiveness of the nanotech's popular science education promotion (NPSEP) and the service-learning courses-Novel Food Processing, Introduction to Food Technology and Bio-nanotechnology.

\section{RESEARCh Methodology AND PROCESSES}

\section{A. Research Procedures}

Three service-learning courses, including Novel Food Processing, Bio-nanotechnology and Introduction to Food Nanotechnology, for the promotion of the popular science of nanotechnology were introduced in this study.

These course aims were developed to teach seed teachers to comprehend the application of nano-materials and nanotechnology in food industry. In order to become seed teachers, undergraduate students who voluntarily took part in service-learning program completed 24 hours extra exercise in NPSEP training, including experimental exercises, Q\&A exercises, design of lesson plans and presentation, beyond classroom learning (see Table I). Seed teachers not only learned about nanotechnology and promotion activity skills, but also collected nanotechnology related fundamental 
knowledge and questions as homework activities. The databases offered them opportunity reference source to develop interactive teaching materials and a question bank for pre- and post-testes. The final lesson plan of NPSEP camp activity included a post-test, lecture, experiment, nano-school (Q\&A competition), and a post-test (see Table II).

TABLE I: THE 24 HOURS RESEARCH AND STUDY COURSE FOR SEED TEACHERS IN NPSEP TRAINING

\begin{tabular}{|c|c|c|}
\hline Schedule & Course & Advisers \\
\hline \multicolumn{3}{|l|}{$1^{\text {st }}$ day } \\
\hline $9: 10 \sim 10: 00$ & Introduction of serve-learning & W. H. Hsu \\
\hline $10: 10 \sim 12: 00$ & Introduction of nanotechnology & H. H. Chen \\
\hline $13: 10 \sim 15: 00$ & Nano-materials and the inspection & Y.P. Yang \\
\hline \multirow[t]{2}{*}{$15: 10 \sim 17: 00$} & $\begin{array}{l}\text { Introduction of nanotech's popular } \\
\text { science education promotion } \\
\text { activity }\end{array}$ & Y. I. Cho \\
\hline & Paper search and reading & Homework \\
\hline $2^{\text {nd }}$ day & Visiting (Nano Technology & H. H. Chen \\
\hline \multirow[t]{6}{*}{$8: 10 \sim 17: 00$} & Research Center of Industrial & Y. I. Cho \\
\hline & Technology Research Institute, & \\
\hline & Nano-Electro-Mechanical-System & \\
\hline & (NEMS) Research Center of & \\
\hline & National Taiwan Univ.) & \\
\hline & $\begin{array}{l}\text { Design the lesson plan of camp } \\
\text { activities }\end{array}$ & Homework \\
\hline \multicolumn{3}{|l|}{$3^{\text {rd }}$ day } \\
\hline $8: 10 \sim 10: 00$ & $\begin{array}{l}\text { Guide practice (Nanotechnology } \\
\text { exhibition space) }\end{array}$ & H. H. Chen \\
\hline \multirow[t]{2}{*}{$11: 10 \sim 12: 00$} & Exercise of nanotech experiment I & Y.P. Yang \\
\hline & & G. C. Tsai \\
\hline $13: 10 \sim 15: 00$ & Exercise of nanotech experiment II & C. T. Chang \\
\hline & & S. M. Lai \\
\hline $15: 10 \sim 16: 00$ & Exercise of Q \& A of nano-school & Y. I. Cho \\
\hline $16: 10 \sim 17: 00$ & $\begin{array}{l}\text { Demonstrate and validate camp } \\
\text { activity }\end{array}$ & W. H. Hsu \\
\hline
\end{tabular}

\section{B. Research Participants}

Totally, 176 students participated in service-learning in the past 5 years (see Table III). Following the guidelines of the service-learning course model [10], the most (72 persons) undergraduates of the Department of Food Science who elected the "Introduction to Food Technology" course in the past 5 years. Therefore, this course was then introduced more detail in this study.

The "Introduction to Food Nano-technology" course introduces the category of nanotechnology, including definition and development of nanotech related to foods technology and industry. The challenges related to classification, properties, preparation, characterization survey, and application of nano-materials were also met in this class according to the text book - Food NanotechnologyFundamental and application, wrote by the instructors (Fig. 1). This course aims were developed to teach seed teachers to comprehend the application of nano-materials and nanotechnology in food industry.

To offer the education resources in remote schools, strategic alliance from four Universities participate the distance learning program. We invited thirteen teachers who are expert in food nanotechnology united to promote this course. There were 857 undergraduate students, including the students in outlying island, who elected the distance learning program in the past 6 years (see Table IV). A text book "Food nanotechnology - fundamental and application" has been compiled according to the course and published as the world's first text book on food nanotechnology with Chinese characters. Among these students in distance learning course, there were 11 students took part in the service learning course as seed teachers for popular science education promotion at 2011. These 11 trained seed teachers were evaluated the learning outcomes and these results were compared with the normal groups who did not participate the service-learning activities.

TABLE II: LESSON PLAN ON POPULAR SCIENCE EDUCATION OF NANOTECHNOLOGY PROMOTED IN ILAN

\begin{tabular}{|c|c|c|}
\hline Subject & $\begin{array}{c}\text { Programs } \\
\text { (teaching/experiment steps) }\end{array}$ & $\begin{array}{c}\text { Duration } \\
(\mathrm{min})\end{array}$ \\
\hline $\begin{array}{l}\text { Did you know } \\
\text { "nano"? }\end{array}$ & $\begin{array}{l}\text { Pre-quiz } \\
\text { To understand how the } 4-6^{\text {th }} \text { grade } \\
\text { students know the nanotechnology. }\end{array}$ & 10 \\
\hline What is "nano"? & $\begin{array}{l}\text { Introduce nanotechnology with } \\
\text { PowerPoint and video. } \\
\text { 1. definition of nanotechnology } \\
\text { 2. nano-materials and } \\
\text { nano-phenomena in nature } \\
\text { 3. application of nanotechnology }\end{array}$ & 30 \\
\hline Visiting & $\begin{array}{l}\text { Introduce nanotechnology to } \\
\text { students in nanotech exhibition } \\
\text { space- } \\
\text { 1. Guide students to learn nanotech } \\
\text { through the model. of biological } \\
\text { nanostructures } \\
\text { 2. Introduction of nano-products in } \\
\text { our daily lives. }\end{array}$ & 30 \\
\hline $\begin{array}{l}\text { Nanotechnology } \\
\text { experiment }\end{array}$ & $\begin{array}{l}\text { Exercise - the smoked paper cup } \\
\text { (Lotus effect) } \\
\text { 1. The bottom of the paper cup, 1/3 } \\
\text { full of water, was smoked by a } \\
\text { candle. Rotate the cup to facilitate } \\
\text { the spreading and adsorption of } \\
\text { carbon particles on the cup } \\
\text { bottom. } \\
\text { 2. The cup was turned upside down } \\
\text { and a blob of water dropped on } \\
\text { the smoked cup bottom. Move the } \\
\text { cup slowly and observe the shape } \\
\text { and rolling of the water blob. } \\
\text { 3. Repeat step } 2 \text { with the other cup } \\
\text { without smoking. } \\
\text { 4. Compare and discuss the } \\
\text { difference in water blob shapes } \\
\text { and spreading between these two } \\
\text { cups. }\end{array}$ & 20 \\
\hline $\begin{array}{l}\text { Q \& A of } \\
\text { nano-school }\end{array}$ & $\begin{array}{l}20 \text { questions about nanotechnology } \\
\text { were divided for } 4 \text { grades } \\
\text { according to difficulty. } \\
\text { The students voluntarily answered } \\
\text { the question and were scored. }\end{array}$ & 30 \\
\hline $\begin{array}{l}\text { I know what is } \\
\text { "nano" }\end{array}$ & $\begin{array}{l}\text { 1. Post-quiz } \\
\text { Same questions in pretest are } \\
\text { examined again to inspect the } \\
\text { efficiency in learning. } \\
\text { 2. Score and compare with the pretest } \\
\text { results. }\end{array}$ & 10 \\
\hline
\end{tabular}

TABLE III: A SUMMARY OF UNDERGRADUATE STUDENTS NUMBER PARTICIPATED THE SERVICE-LEARNING COURSES

\begin{tabular}{|c|c|c|c|c|c|c|c|c|c|}
\hline \multirow[t]{2}{*}{$\begin{array}{r}\text { Year \& } \\
\text { semester }\end{array}$} & \multicolumn{2}{|c|}{2009} & \multicolumn{2}{|c|}{2010} & \multicolumn{2}{|c|}{2011} & 2012 & 2013 & \multirow[t]{2}{*}{ Sum } \\
\hline & A & $\mathrm{B}$ & A & B & A & $\mathrm{B}$ & A B & A $\mathrm{B}$ & \\
\hline $\begin{array}{l}\text { Novel Food } \\
\text { Processing }\end{array}$ & & 44 & & & & & & & 44 \\
\hline $\begin{array}{l}\text { Introduction to Food } \\
\text { Nanotechnology }\end{array}$ & & & 10 & & 11 & & 11 & 40 & 72 \\
\hline Bio-nanotechnology & & & & 22 & & 11 & 11 & 16 & 60 \\
\hline Sum & & 4 & & 2 & & 2 & 22 & 56 & 176 \\
\hline
\end{tabular}




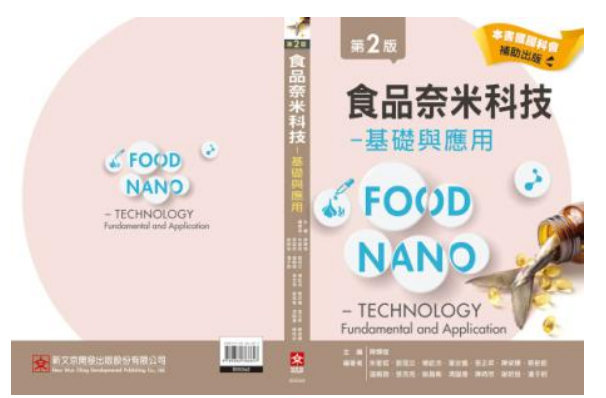

Fig. 1. The text book "Food nano-technology: Fundamental and application $\left(2^{\text {nd }} \mathrm{Ed}\right.$.)" of the course - Introduction to food nano-technology.

TABLE IV: A SUMMARY OF STUDENTS NUMBER IN THE COURSE INTRODUCTION TO FOOD NANO-TECHNOLOGY

\begin{tabular}{lccccccc}
\hline \multicolumn{1}{c}{ School year } & & & & & & & \\
& 2008 & 2009 & 2010 & 2011 & 2012 & 2013 & Sum \\
Participating schoos & & & & & & & \\
\hline National Ilan Univ. & 34 & 39 & 42 & 47 & 51 & 67 & $\mathbf{2 8 0}$ \\
\hline $\begin{array}{l}\text { National Chung Hsing } \\
\text { Univ. }\end{array}$ & 11 & 7 & 6 & 6 & 16 & 9 & $\mathbf{5 5}$ \\
\hline $\begin{array}{l}\text { National Penghu Univ. } \\
\text { of Sci. and Technol. }\end{array}$ & 9 & 15 & 42 & 35 & 63 & 35 & $\mathbf{1 9 9}$ \\
\hline National Quemoy Univ. & 30 & 18 & 24 & 47 & 44 & 59 & $\mathbf{2 2 2}$ \\
\hline St. John's Univ. & & & & 2 & & 6 & $\mathbf{8}$ \\
\hline $\begin{array}{l}\text { National Kaohsiung } \\
\text { Marine Univ. }\end{array}$ & & & & 18 & 13 & $\mathbf{3 1}$ \\
\hline Chinese Culture Univ. & & & & & 19 & 20 & $\mathbf{3 9}$ \\
\hline Chinese Culture Univ. & $\mathbf{8 4}$ & $\mathbf{7 9}$ & $\mathbf{1 1 4}$ & $\mathbf{1 3 7}$ & $\mathbf{2 1 1}$ & $\mathbf{2 3 2}$ & $\mathbf{8 5 7}$ \\
\hline Total & & & & & & \\
\hline \hline
\end{tabular}

The research participants included 323 high-grade students (10 to 12 years old) in 12 classes in four elementary schools in I-Lan city. In view of the effectiveness of the NPSEP activity of service-learning course in I-Lan area, the selection of high-grade students in four elementary schools in I-Lan city as the research objects. To compare the learning efficiency of seed teachers with normal students, 5 point scale was utilized to evaluate the degree of understanding about nanotechnology after the course and NPSEP activity.

\section{Research Tools}

This study investigated the effectiveness of the NPSEP for service-learning course through the variations analysis of learning performance before and after camp activity. A draft of nanotech's questionnaire was developed by seed teachers. The pre-test was performed by inviting a total of 10 students $\left(6^{\text {th }}\right.$ grade) to take the test and enabled students to describe the problem and proposed amendments. Two professors of nanotech expertise and four elementary school teachers then reviewed the amended questionnaire and questions dimension. The final questionnaire of NPSEP test, which completed with content validity and expert validity, included 15 questions with 10 true or false question and 5 multiple-choice questions. The design of the six dimensions in the test included: optical crystal effect; lotus effect; surface effect; month-eye effect; carbon nano-tube; definition, characteristics and application of nanotech. According to the analysis of 48 high-grade students in K elementary school, the reliability of internal consistency (KR20) is 0.78 , the difficulty of the questions is 0.35 to 0.81 , and the discrimination of these questions is 0.23 to 0.85 . It exhibited that the "NPSEP test" is appropriate for reliability and validity to study the learning effectiveness of NPSEP camp activity.

\section{Data Collection and Analysis}

In this study, the $6^{\text {th }}$ grade students attended NPSEP camp activity and NPSEP test. The scoring criteria of the test were 1 or 0 point obtained for the correct or incorrect answer, respectively, to up to 15 points. The SPSS 10.0 software was utilized to analyze the test results by descriptive statistics, paired sample t-test, ANOVA and post-hoc comparison. When ANOVA revealed a significant effect $(P<0.05)$, data means were compared using a least significant difference (LSD) test. Furthermore, the effectiveness of NPSEP activity in service-learning course was investigated.

\section{RESUlTS AND DISCUSSION}

The effectiveness of service-learning and NPSEP in I-Lan city was discussed as follow.

\section{A. The Effectiveness of NPSEP on Elementary School Student}

The four elementary school students in I-Lan Area who participated in this study, conducted "NPSEP test" before and after the NPSEP camp activity. The descriptive statistics of these test results are shown in Table V. In respect of the overall performance of schoolchildren, the score before and after camp activity were 8.94 and 13.33 points, respectively. These schoolchildren made 4.39 point progress through the NPSEP camp activity. The paired sample t-test analysis showed that significant difference between the pre-test scores and post-test results of these schoolchildren $(t=-36.47$, $p=0.000$ ). This result revealed that the NPSEP significantly upgrade academic performance in nanotechnology for elementary school student. In the other words, the effectiveness of learning in this NPSEP activity is quite commendable.

TABLE V: NANOTECHNOLOGY SCIENCE EDUCATION TEACHING EFFECTIVENESS OF 4 ELEMENTARY SCHOOLS IN ILAN CITY

\begin{tabular}{cccccc}
\hline \hline School & $\begin{array}{c}\text { Number } \\
\text { of } \\
\text { students }\end{array}$ & $\begin{array}{c}\text { Pre-test } \\
\text { scores } \\
\text { (Mean } \pm \text { sd.) }\end{array}$ & $\begin{array}{c}\text { Post-test } \\
\text { scores } \\
\text { (Mean } \pm \text { sd.) }\end{array}$ & $t$-value & $p$-value \\
\hline $\mathrm{L}$ & 106 & $9.13 \pm 1.87$ & $13.13 \pm 1.70$ & -20.35 & 0.000 \\
$\mathrm{~K}$ & 139 & $8.61 \pm 1.97$ & $13.15 \pm 1.74$ & -24.03 & 0.000 \\
$\mathrm{Y}$ & 48 & $8.79 \pm 1.71$ & $14.23 \pm 1.13$ & -18.95 & 0.000 \\
$\mathrm{G}$ & 30 & $10.03 \pm 1.77$ & $13.47 \pm 1.46$ & -9.68 & 0.000 \\
\hline \hline
\end{tabular}

For individual elementary schoolchildren, the score before and after camp activities were in the range of 8.61-10.03 and 13.13-14.23 points, respectively. The paired samples t-test analysis of pre-test and post-test scores showed that each of the elementary school students made progress significantly after NPSEP camp activity ( $p=0.000$ ). The results revealed that the NPSEP camp activity significantly enhanced the academic performance of each elementary school children. In other words, the effectiveness of NPSEP activity is remarkable and NPSEP lesson plan is a suitable candidate for inclusion in nanotechnology education promotion

The variation between pre-test and post-test score for these four elementary school students was in the order of $Y>K>L>G$. According to the single-factor analysis of such variation, homogeneity of variance was observed among these four elementary schools. The Scheffe method for 
post-hoc comparison was then performed and found that $\mathrm{Y}$ school's learning outcomes significantly better than that of $G$ and L School. However, there was no significant difference between $\mathrm{K}$ and Y school as well as between $\mathrm{G}$ and L school. Such results require further investigation to clarify the variation in learning effectiveness among these four elementary schools.

\section{B. The Effectiveness of Service-Learning}

Reflection is the main difference between service-learning and community service. The 11 undergraduate students wrote day records, searched and read related data, had discussions, and designed lesson plans. It was unfamiliar and hard work. Most of the undergraduate students were afraid and some of them even regretted participating in the service-learning course during training. Nevertheless, these seed teachers matured after the camp activity and learned more nano-science and experiments than previously used in their classroom. Almost all of the seed teachers got excellent scores after evaluation by elementary school teachers regarding their attitude, skills and knowledge.

The 11 undergraduate students' final reports on the service-learning course expressed the fact that they were overjoyed that they had greatly benefited from service-learning. The average degree of understanding about food nanotechnology after the course in 3 topics and 20 learning targets for undergraduate seed teachers $(n=11)$ were higher than those of control (normal students, $n=28$ ). For normal group, the degree of understanding was 3.13 and 3.90 before and after course, respectively. For NPSEP seed teacher, the degree of understanding was 3.13 and 4.18 before and after course, respectively. According to the questionnaire survey (see in Table VI), these undergraduate seed teachers gained a more significant advancement in learning target of food nanotechnology $(P<0.05)$.

TABLE VI: COMPARE THE LEARNING EFFICIENCY OF NORMAL STUDENTS WITH THAT OF SEED TEACHERS

\begin{tabular}{ccccc}
\hline \multirow{2}{*}{ Topic } & \multicolumn{4}{c}{ Degree of understanding (average data) } \\
\cline { 2 - 5 } & \multicolumn{2}{c}{ Normal groups $(n=28)$} & \multicolumn{2}{c}{ Seed teachers $(n=11)$} \\
\cline { 2 - 5 } & $\begin{array}{c}\text { Before } \\
\text { teaching }\end{array}$ & $\begin{array}{c}\text { After } \\
\text { teaching }\end{array}$ & $\begin{array}{c}\text { Before } \\
\text { teaching }\end{array}$ & $\begin{array}{c}\text { After } \\
\text { teaching }\end{array}$ \\
\hline $\begin{array}{c}\text { Nano-materials and } \\
\text { nano-tech in food }\end{array}$ & 3.17 & 3.93 & 3.19 & 4.21 \\
\hline $\begin{array}{c}\text { Application of food } \\
\text { nano-tech }\end{array}$ & 3.17 & 3.93 & 3.14 & 4.32 \\
\hline $\begin{array}{c}\text { Development of food } \\
\text { nano-tehnology }\end{array}$ & 3.05 & 3.83 & 3.06 & 3.97 \\
\hline \begin{tabular}{l} 
Average \\
\hline a-c Different superscripts represent significantly different $(P<0.05)$.
\end{tabular}
\end{tabular}

\section{CONCLUSION}

The positive effectiveness is significant for the developed NPSEP activity and the learning outcome in nanotech for elementary schools students also had significantly promoted. Undergraduate students not only learned about the nanotechnology knowledge, particularly in food nanotech, but also become actively contributing citizens through the service and learning. Through NPSEP activities, teaching others teaching themselves, both undergraduate students and elementary schoolchildren can benefit.

\section{ACKNOWLEDGMENT}

The author wishes to thank the National Science Council (NSC 101-2120-S-197-001) for financial support of this study, and also express appreciation for the assistance of students of Nano-Biomaterial Application Lab in Ilan University and the teachers/students of the elementary schools who participated in this program.

\section{REFERENCES}

[1] A. Hullmann. (2005). Nanotechnology, Europe and the world: The international dialogue in nanotechnology. [Online]. Available: www.ics.trieste.it/Documents/Downloads/ df2625

[2] X. Z. Lee, S. H. Wu, and L. Fan, "Preliminary study on the development to student modeling capabilities of nanotechnology teaching," Science Education Month Magazine, vol. 309, pp. 2-4, Jan. 2008.

[3] NSET. (May 2003). NNI grand challenge workshop: Nanoscale processes for environmental improvement. [Online]. Available: http://www.nano.gov

[4] Z. Herbert, Television Production Handbook, 9th ed., Belmont, CA: Wadsworth, 2000, pp. 1-5.

[5] W. S. Bainbridge, "Sociocultural meanings of nanotechnology: Research methodologies," Journal of Nanoparticle Research, vol. 6, pp. 285-299, June 2004.

[6] M. Telford, "Building a nano workforce from the bottom up," Materials Today, vol. 7, pp. 1-18, December 2004.

[7] J. F. Groves, "The Virginia partnership for nanotechnology education and workforce development," in Proc. $38^{\text {th }}$ ASEE/IEEE Frontiers in Education Conference, Saratoga Springs, N.Y., Oct. 22-25, 2008, pp. F4F-7 - F4F-11.

[8] W. C. Crone, "Bringing nano to the public through informal science education," presented at the 2008 APS March Meeting, New Orleans, Louisiana, March 10-14, 2008.

[9] C. H. Lin, "Integrating service-learning into pre-service teacher training: An example of e-tutor program," M.S. thesis, Graduate Institute of Learning and Instruction, National Central Univ., Taoyuan, Taiwan, 2007.

[10] L. Y. Feng, "A study of service learning in higher education," $J$ National Taichung Teachers College, vol. 19, pp. 1-19, Jan. 2005.

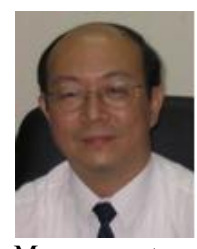

Ming-Ta Wu was born in I-Lan, Taiwan. He graduated and received Ph.D. from the Department of Industrial Education, National Taiwan Normal University, Taiwan, R.O.C. His major field of study is industrial education and quality control. He has been the professor of National Ilan University and the president of Aletheia University. Now, he is a professor of the Department of Industrial Management and Enterprise Information, Aletheia University. Dr. Wu has published 20 journal papers, 1 Books and 33 conference papers.

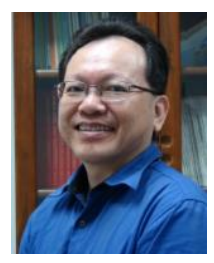

Hui-Huang Chen was born in Chia-Yi, Taiwan on July 12, 1960. He graduated from Institute of Marine Food Science, National Taiwan Ocean University, Taiwan, R.O.C. and received Ph.D. in June, 1991. His major field of study is food science and technology.

He has been the Q.C. Leader of Hsin-Yi Frozen Food Industry Co. Ltd. (Nov. 1982 - Jul. 1987). Now, he is the distinguished professor, Department of Food Science, and the director of Center for Nanotechnology, National Ilan University. He has published 74 journal papers, 15 Books, including the text book "Food Nano-technology: Fundamental and Application (Taipei, New Wun Ching Developmental Publishing, 2011", and also held 2 patents. His research interests included food processing, nano bio-materials application, physical properties of food, seafood science and technology. He has been the principal and/or research associate of more than 80 projects directly related to the marine food science, the manufacturing technique of local products in I-Lan and the nanotechnology applied in food.

Professor Dr. Chen is the professional member of Institute of Food Technologist (USA), Taiwanese Institute of Food Science and Technology (director within 2009-2011). He has owned the award of "Outstanding Teaching Award" and "Outstanding Teaching Award" of National Ilan University, Awards for Subsidization Program in Colleges and Universities for Encouraging Exceptional Talent from the National Science Council of Taiwan. Professor Chen is also the committee of Food Labeling Advertising Advisory Council of Ministry of Health and Welfare. 